\title{
Aa. Vv., «Bulletin des Amis d'André Gide», n. 155
}

\section{Emanuele Kanceff}

\section{(2) OpenEdition}

\section{Journals}

\section{Edizione digitale}

URL: http://journals.openedition.org/studifrancesi/9657

DOI: 10.4000/studifrancesi.9657

ISSN: 2427-5856

\section{Editore}

Rosenberg \& Sellier

\section{Edizione cartacea}

Data di pubblicazione: 1 décembre 2007

Paginazione: 694

ISSN: 0039-2944

\section{Notizia bibliografica digitale}

Emanuele Kanceff, «Aa. Vv., «Bulletin des Amis d'André Gide», n. 155», Studi Francesi [Online], 153 (LI III) | 2007, online dal 30 novembre 2015, consultato il 12 janvier 2021. URL: http://

journals.openedition.org/studifrancesi/9657 ; DOl: https://doi.org/10.4000/studifrancesi.9657

Questo documento è stato generato automaticamente il 12 janvier 2021.

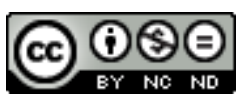

Studi Francesi è distribuita con Licenza Creative Commons Attribuzione - Non commerciale - Non opere derivate 4.0 Internazionale. 


\title{
Aa. Vv., «Bulletin des Amis d'André Gide», n. 155
}

\author{
Emanuele Kanceff
}

\section{NOTIZIA}

«Bulletin des Amis d'André Gide», n. 155, XL année, vol. XXXV, juillet 2007, pp.

$365-524$.

Dopo un articolo di Catherine GRAVET, D'un portrait graphologique: «infiniment séduisant», in cui si disquisisce sulla "scienza" della grafologia ma ci si arricchisce anche di notizie su Gide, Hélène Legros, Aline Mayrisch e soprattutto sul protagonista, Alexis Curvers, il fascicolo si costruisce attorno a due temi: "Autour de Corydon», con il dossier preparatorio del romanzo e le lettere raccolte da Gide, il tutto presentato da Alain GOULET, e «Souvenirs et témoignages», con lo scritto di Jean-Marie PAISSE, Une rencontre mémorable, l'incontro con Gide dell'autore allora giovinetto. Tra i due s'inseriscono le consuete puntate dei diari inediti di Robert Levesque e di Jean Lambert. Seguono, poi, le consuete rubriche, che comprendono i Dossiers de presse di Feuilles de route e di Thésée. 